\title{
Assessing Student Acceptance of Digital Repository as Knowledge Management System to Support Research Activities
}

\author{
Yeni Anistyasari \\ Department of Computer Science and Information Engineering \\ National Taiwan University of Science and Technology \\ Taipei, Taiwan \\ yenian@unesa.ac.id
}

\author{
Ari Kurniawan ${ }^{1}$, Imami Arum Tri Rahayu ${ }^{2}$, Amalia Ruhana ${ }^{2}$ \\ Department of Informatics ${ }^{1}$, \\ Department of Home Economics ${ }^{2}$ \\ Universitas Negeri Surabaya \\ Surabaya, Indonesia
}

\begin{abstract}
Digital repositories play an important role for knowledge management. They propose a useful infrastructure through which to store, manage, and reuse digital materials. Studies in exploring digital repositories have been applied in several higher educations. However, the acceptance of digital repositories in higher education is lack of being explored. This study therefore proposes an appropriate conceptual model for the intention to use digital repositories by adopting technology acceptance model that consists of three dimensions namely perceived usefulness, ease of use, and intention to use. The first stage of this study was analyzing related research to devise a questionnaire and conduct a survey for lecturers and students. Questionnaires are then completed to evaluate users' acceptance of digital repository. The analysis reveals that the proposed factors positively influence users' intention to digital repositories. The managerial implications and suggestion to introduce such system are provided accordingly.
\end{abstract}

Keywords-digital repositories, knowledge management system, user acceptance

\section{INTRODUCTION}

The rapid growth of data and technologies influences the transformation of data to valuable information which is defined as knowledge. The academic societies are more concerned on the importance of knowledge and methods to obtain, identify, encapsulate, retrieve, utilize or measure, manage and share the knowledge in the form of knowledge artifacts. Furthermore, the process involves in managing the knowledge is known as knowledge management [1]. A wellknown information system for knowledge management is digital repository.

The development of higher education's digital repository helps improving student's, lecturer's, and manager's productivities since it offers ubiquity, flexibility, and advanced search features better than a traditional repository [2]. This is to say, higher education is no longer just offering knowledge to students and lecturers, but also having to manage and share the existing knowledge for upcoming research reference. The use of digital repository for knowledge management system in higher education have been widely applied [1-5].
The acceptance of digital repository however has not been deeply explored. The effectiveness, efficiency, satisfaction and awareness have positive impact on the usage of digital repository. In addition, students agree that the repository increases their visibility on improving research because they have opportunity to interact with other scholars in worldwide [5]. On the other hand, a recognized model to measure the degree of digital repository acceptance is technology acceptance model (TAM) [6]. TAM consists of perceived ease of use (PEU), perceived usefulness (PU), and intention to use (IU). PU is a degree to which a person considers that utilizing a particular information system will improve job performance. PEU is a degree to which a person is confident in using a particular information system that engages minimal effort. The amount of effort that is required to use an innovation will have an effect on the adopter's sense of self-efficacy with regard to using the innovation which is a definition of IU. Some studies have dealt with TAM to evaluate digital repository [7-11]. TAM that includes perceived usefulness, perceived ease of use, and intention to use is used to evaluate the effectivity of information technology for library. The findings revealed that those variables affect the acceptance of information technology for library.

The aim of this study is to examine the determinant factors in the acceptance of digital repository. Furthermore, the contribution is to accomplish the utilization of technology acceptance model to evaluate the digital repository as a knowledge management system in higher education. TAM is explored extensively as a research framework to explore the applicability of the model.

\section{METHOD}

This study was mainly based on TAM including perceived ease of use (PEU), perceived usefulness (PU), and intention to use (IU) as illustrated in fig 1. H1, H2, and H3 respectively indicated hypothesis 1, hypothesis 2, and hypothesis 3 . The detail explanation of $\mathrm{H} 1, \mathrm{H} 2$, and $\mathrm{H} 3$ is listed in Table I. 
TABLE I. RESEARCH HYPOTHESIS

\begin{tabular}{|c|l|}
\hline Hypothesis id & \multicolumn{1}{|c|}{ Hypothesis } \\
\hline $\mathrm{H} 1$ & $\begin{array}{l}\text { Perceived usefulness is positively related to digital } \\
\text { repository user's intention to use }\end{array}$ \\
\hline $\mathrm{H} 2$ & $\begin{array}{l}\text { Perceived ease of use is positively related to digital } \\
\text { repository intention to use }\end{array}$ \\
\hline
\end{tabular}

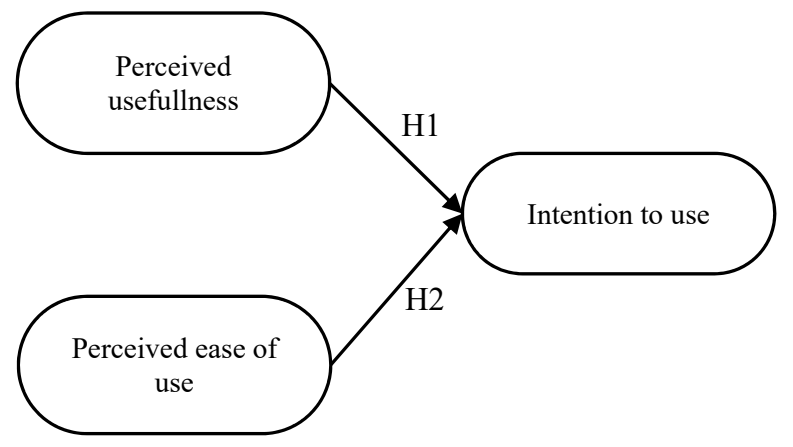

Fig. 1. Research model

The sample of this study was 60 higher education students at Department of Informatics, Universitas Negeri Surabaya, Indonesia. 70 percent of them were female students and the remaining were male students aged 18-20 years old. The respondents were randomly selected from informatics, information system, information management, and information technology education study programs.

Respondents were requested to complete TAM questionnaire which was adapted from [12]. 5-point Likert scale was used to measure the questionnaire scale. The reason of using 5-point Likert scale was in most cases, a 5point Likert Scale was the most reliable measuring model. The responses rated as follows: 1 as strongly disagree, 2 as disagree, 3 as somewhat agree, 4 as agree, and 5 as strongly agree.

The architecture of digital library which was evaluated in this study was depicted in Fig 2. The architecture had three layers including server, middleware, and client application. Server served for maintaining collections of metadata labelling the collection's properties. In addition, it was for executing query and retrieval mechanisms for metadata. The collection was defined as catalog. Middleware applied standard services for collections. Client application presented the services to digital repository users [13].

The five standards of digital library architecture for client interfaces were as follows.

- Session is to create or terminate a logical "session" between client and middleware

- Catalog is the list of library collections maintained by the middleware

- Search identifies library properties that satisfy specific Boolean constraints on standard high-level search-oriented metadata
- Metadata is to retrieve metadata for specified library properties.

- Properties is to demand the library property, or information on how to retrieve the property.

\section{RESUlt AND Discussion}

Respondents were requested to complete TAM questionnaire which was adapted from [12]. 5-point Likert scale was used to measure the questionnaire scale. The reason of using 5-point Likert scale was in most cases, a 5point Likert Scale was the most reliable measuring model. The responses rated as follows: 1 as strongly disagree, 2 as disagree, 3 as somewhat agree, 4 as agree, and 5 as strongly agree. The TAM questionnaire are listed in Table II.

The reliability of questionnaire was measured by Cronbach's alpha of each construct. The Cronbach's alpha results for PEU, PU, and IE respectively were $0.88,0.90$, and 0.92 while the critical value was 0.6 . Since the Cronbach's alpha values were greater than the critical value, the questionnaire was reliable. Kaiser-Meyer-Olkin (KMO) analysis results for PU, PEU, and IU respectively were 0.65 , 0.74 , and 0.70 . KMO value of each construct was greater than 0.5 which meant that questionnaire satisfy construct validity threshold. The results of Cronbach's alpha and KMO analysis were itemized in Table III. Furthermore, the average questionnaire value of PU was 4.49, PEU was 4.50, and IU was 4.51. The average value and standard deviation of questionnaire were listed in Table IV.

TABLE II. QUESTIONNAIRE

\begin{tabular}{|c|c|}
\hline Constructs & Statements \\
\hline $\begin{array}{l}\text { Perceived } \\
\text { usefulness } \\
\quad(\mathrm{PU})\end{array}$ & $\begin{array}{l}\text { 1. Using the digital repository would improve my } \\
\text { performance in conducting my research } \\
\text { 2. Using the digital repository at work would improve } \\
\text { my productivity in research } \\
\text { 3. Using the digital repository would enhance my } \\
\text { effectiveness in conducting my research } \\
\text { 4. I would find the digital repository useful in } \\
\text { conducting my research }\end{array}$ \\
\hline $\begin{array}{l}\text { Perceived ease } \\
\text { of use (PEU) }\end{array}$ & $\begin{array}{l}\text { 1. Learning to operate the digital repository would be } \\
\text { easy for me } \\
\text { 2. I would find it easy to get the digital repository to do } \\
\text { what I want it to do } \\
\text { 3. It would be easy for me to become skillful in the use } \\
\text { of the digital repository } \\
\text { 4. I would find the digital repository easy to use }\end{array}$ \\
\hline $\begin{array}{l}\text { Intention to } \\
\text { use (IU) }\end{array}$ & 1. I am willing to use the digital repository \\
\hline
\end{tabular}

TABLE III. RELIABILITY AND VALIDITY SCORES

\begin{tabular}{|c|c|c|}
\hline Constructs & Cronbach's alpha & KMO \\
\hline Perceived usefulness (PU) & 0.90 & 0.65 \\
\hline Perceived ease of use (PEU) & 0.88 & 0.74 \\
\hline Intention to use (IU) & 0.92 & 0.70 \\
\hline
\end{tabular}




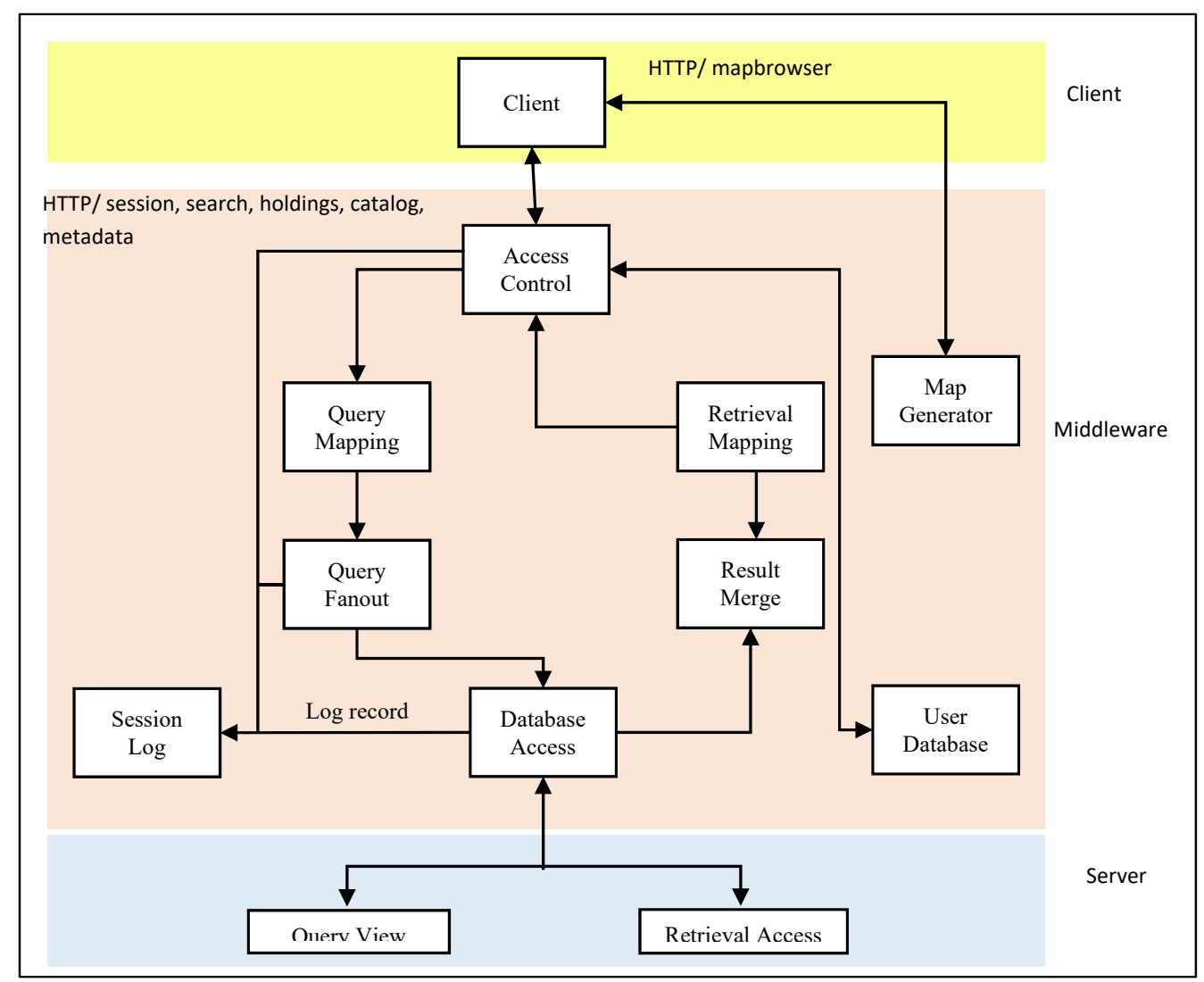

Fig. 2. Digital Repository Architecture

TABLE IV. AVerage Value and Standard Deviation

\begin{tabular}{|c|c|c|}
\hline Items & Mean & Standard Deviation \\
\hline PU1 & 4.5167 & 0.50394 \\
\hline PU2 & 4.4667 & 0.50310 \\
\hline PU3 & 4.4333 & 0.49972 \\
\hline PU4 & 4.5667 & 0.49972 \\
\hline PEU1 & 4.4000 & 0.49403 \\
\hline PEU2 & 4.4000 & 0.49403 \\
\hline PEU3 & 4.5833 & 0.49717 \\
\hline PEU4 & 4.5833 & 0.49717 \\
\hline IU1 & 4.5500 & 0.50169 \\
\hline
\end{tabular}

The relations between variables were analyzed using Pearson product moment correlation coefficient. Each construct was tested and the Pearson product moment correlation coefficients were ranging from 0.37 to 0.47 as stated in Table V. The results revealed that factors of technology acceptance model were positively correlated with each other.

Statistical analysis was then conducted to test the hypotheses. Additionally, the results were organized in Table
VI. According to B value, linier regression was formulated as follow:

$\mathrm{Y}=2.186+0.72 \mathrm{X} 1+0.77 \mathrm{X} 2$

where $\mathrm{X} 1$ is PU and $\mathrm{X} 2$ is PEU. The equation meant that if PU and PEU were 0 , IU was 2.186. Regression coefficient of PU was 0.72 which indicated PU and IU were positively related. This is to say, the greater perceived usefulness, the greater intention to use digital repository.

TABLE V. CORRELATION ANALYSIS

\begin{tabular}{|c|c|c|c|}
\hline & PU & PEU & IU \\
\hline Perceived usefulness (PU) & 1 & & \\
\hline Perceived ease of use (PEU) & 0.37 & 1 & \\
\hline Intention to use (IU) & 0.46 & 0.47 & 1 \\
\hline
\end{tabular}


TABLE VI. PU AND PEU COEFFICIENTS TO IU

\begin{tabular}{|c|c|c|c|c|c|}
\hline & \multicolumn{2}{|c|}{$\begin{array}{c}\text { Unstandardized } \\
\text { Coefficients }\end{array}$} & \multirow{2}{*}{$\begin{array}{c}\begin{array}{c}\text { Standardized } \\
\text { Coefficients }\end{array} \\
\text { Beta }\end{array}$} & \multirow[t]{2}{*}{$\mathbf{t}$} & \multirow[t]{2}{*}{ Sig. } \\
\hline & B & $\begin{array}{c}\text { Std. } \\
\text { Error }\end{array}$ & & & \\
\hline 1 (Constant) & 2.186 & 1.313 & & 1.949 & 0.000 \\
\hline $\mathrm{PU}$ & 0.72 & 0.198 & 0.048 & 3.63 & 0.008 \\
\hline PEU & 0.77 & 0.207 & 0.049 & 3.73 & 0.007 \\
\hline
\end{tabular}

Furthermore, according to Table IV, the significance value of PU was 0.008 , which was less than 0.05 , this was to say that perceived usefulness significantly affected user's intention to use. The significance value of perceived ease of use was 0.007 , which was less than 0.05 . It indicated that perceived ease of use had a significant effect to user's intention to use.

\section{CONCLUSION}

This study adapts technology acceptance model (TAM) questionnaire to evaluate students' acceptance of digital repository to improve research activity. The statistical analysis results reveal that perceived of use has significantly affect user's intention to use as well as perceived ease of use does. This study however has limitation which is path analysis to evaluate each item of constructs and will accomplish for further study.

\section{REFERENCES}

[1] M. A. Ismail, M. Yaacob, and S. A. Kareem, "Institutional Repositories : Review and Knowledge Management Perspective," in Knowledge Management International Conference 2008, 2008, pp. 333-338.

[2] J. F. Salm Jr, R. C. dos S. Pacheco, and V. M. Kern, "From digital repository to knowledge management system: the theses and dissertations database of PPGEP/UFSC," Proc. 6th Int. Conf. Curr. Res. Inf. Syst. - Cris, vol. 2000, no. January 2015, pp. 95-102, 2002.

[3] M. Munawaroh and D. E. Prayitno, "Digital Library and Institutional Repository for Supporting Information Literacy," Rec. Libr. J., vol. 1, no. 2, p. 161, 2016

[4] J.-H. Yeh, J.-Y. Chang, and Y.-J. Oyang, "Content and knowledge management in a digital library and museum," J. Am. Soc. Inf. Sci., vol. 51, no. 4, pp. 371-379, 2000.

[5] J. Achieng, "An Analysis Of The Usage Of A Digital Repository In An Academic Institution," 2016

[6] P. Lai, "the Literature Review of Technology Adoption Models and Theories for the Novelty Technology," J. Inf. Syst. Technol. Manag., vol. 14, no. 1, pp. 21-38, 2017.

[7] F. Sheikhshoaei and T. Oloumi, "Applying the technology acceptance model to Iranian engineering faculty libraries," Electron. Libr., vol. 29, no. 3, pp. 367-378, 2011.

[8] Z. N. Wynn, T. Winn, and S. M. Syed-mohamad, "Technology Acceptance Model for Web-based Repository of Health Education Materials," in International Conference on Management and Education Innovation, 2012, vol. 37, pp. 189-195.

[9] S. Corrall, "The Role Of The Technology Acceptance Model in Information Systems Research: A Case Study," Proc. IADIS Int. Work. Inf. Syst. Res. Trends, Approaches Methodol., vol. 64, pp. 49-67, 2011.

[10] S. Alharbi and S. Drew, "Using the Technology Acceptance Model in Understanding Academics' Behavioural Intention to Use Learning Management Systems," Int. J. Adv. Comput. Sci. Appl., vol. 5, no. 1, 2014.

[11] F. Y. Pai and K. I. Huang, "Applying the Technology Acceptance Model to the introduction of healthcare information systems," Technol. Forecast. Soc. Change, vol. 78, no. 4, pp. 650-660, 2011.
[12] M. Turner, B. Kitchenham, P. Brereton, S. Charters, and D. Budgen, "Does the technology acceptance model predict actual use? A systematic literature review," Inf. Softw. Technol., vol. 52, no. 5, pp. 463-479, 2010.

[13] J. Frew et al., "The Alexandria digital library architecture," Int. J. Digit. Libr., vol. 2, no. 4, pp. 259-268, 2000. 